\title{
ESTRATÉGIAS DA FABER-CASTELL BRA- SIL NO FACEBOOK PARA AMPLIAR SUA VISIBILIDADE NA AMBIÊNCIA DIGITAL
}

\author{
RAÍSSA GRÍGOLO DA SILVA \\ UNIVERSIDADE FRANCISCANA \\ SANTA MARIA, RIO GRANDE DO SUL, BRASIL \\ RAISSA_GRIGOLO@HOTMAIL.COM \\ TAÍS STEFFENELLO GHISLENI \\ UNIVERSIDADE FRANCISCANA \\ SANTA MARIA, RIO GRANDE DO SUL, BRASIL \\ TAISGHISLENI@YAHOO.COM.BR
}




\section{ESTRATÉGIAS DA FABER-CASTELL BRASIL NO FACEBOOK PARA AMPLIAR SUA VISIBILIDADE NA AMBIÊNCIA DIGITAL}

Resumo: O presente trabalho foi desenvolvido com o objetivo de analisar as estratégias comunicacionais da marca Faber-Castell Brasil, que concentra seus esforços na área comunicacional para o contexto da ambiência digital. O estudo foi realizado a partir das observações de postagens da organização em sua página no Facebook, nos meses de junho e julho de 2017. Com caráter qualitativo quantitativo, através do método de análise de conteúdo, foi possível verificar que a Faber-Castell Brasil carrega, de forma subjetiva, seu posicionamento e mantém, em sua comunicação, a essência dos produtos que a marca comercializa.

Palavras Chave: Comunicação; Ecossistema digital; Estratégias Comunicacionais; Visibilidade; Faber-Castell.

ESTRATEGIAS DE FABER-CASTELL BRASIL EN FACEBOOK PARA AUMENTAR SU VISIBILIDAD EN EL ENTORNO DIGITAL

Resumen: El presente trabajo fue desarrollado con el objetivo de analizar las estrategias comunicacionales de una marca ya consolidada, que concentra sus esfuerzos en esa área para el contexto del ambiente digital. El estudio fue realizado a partir de las observaciones de posturas de la organización en su página en Facebook, en los meses de junio y julio de 2017. Con carácter cualitativo cuantitativo, a través del método de análisis de contenido, fue posible verificar que Faber-Castell Brasil carga de forma subjetiva su posicionamiento y mantiene en su comunicación, la esencia de los productos que la marca comercializa.

Palabras Clave: Comunicación; Ecosistema digital; Estrategias de comunicación; visibilidad; Faber-Castell.

\section{FABER-CASTELL BRASIL STRATEGIES ON FACEBOOK TO INCREASE YOUR VISIBILITY IN THE DIGITAL ENVIRONMENT}

Abstract: The present work was developed with the objective of analyzing how the communication strategy of a brand already consolidated, that concentrate its activities in this area to context of the digital environment. The study was carried out based on the observations of the organization's postings on its Facebook page, in June and July 2017. With quantitative qualitative character, through the content analysis method, it was possible to verify that Faber-Castell Brazil carries subjectively its positioning and maintains in its communication, an essence of the products that the brand trades. Key-words: Communication; Digital Ecosystem; Communication strategies; Visibility; Faber-Castell. 


\section{INTRODUÇÃO}

Com o avanço da tecnologia, a comunicação passou por inúmeras mudanças, permitindo, por exemplo, que indivíduos localizados a quilômetros de distância, se encontrem e conversem instantaneamente, seja por meio de computadores ou qualquer outro dispositivo que possibilite a troca de mensagens. Gabriel (2018, p. 13) chama atenção para o fato de que "toda nova tecnologia é tanto uma benção como um fardo: a introdução das tecnologias no mundo traz tanto novas possibilidades a explorar como novos desafios a serem enfrentados". Nesta perspectiva, os impactos causados pelas mudanças trazem novas possibilidades, mas também novos desafios.

A evolução da tecnologia trouxe muitos benefícios não só para o relacionamento interpessoal, mas no modo como as empresas e seus consumidores interagem. Esse público ganhou voz e passou de mero receptor de mensagens para coprodutor de conteúdo das marcas, exercendo um papel bem mais amplo neste processo. Angeloni (2010, p.13) afirma que "as pessoas passam então a contribuir no campo das decisões". Assim, cabe às marcas identificar, a partir do perfil de seu mercado-alvo, as estratégias mais eficazes para manter o interesse dos compradores.

Dentro desse contexto, pode-se considerar que no ambiente digital os acontecimentos ganham uma velocidade intensa e muita informação fica disponível para o público, que passa a ficar mais seletivo, por isso, as organizações precisam trabalhar a sua visibilidade e criar uma forte presença digital. Lembrando sempre que as mudanças que influenciam a vida do público-alvo devem estar ancoradas no posicionamento da empresa. E as mensagens que a instituição usa nas mídias tradicionais, devem estar de acordo com as que são transmitidas no ambiente digital, levando em consideração que as plataformas são diferentes. Além disso, deve haver uma adaptação na mensagem que será transmitida, precisando essa estar combinada em todos os meios que a marca estiver, para que, dessa maneira, a comunicação se torne integrada e a visibilidade da mesma fortalecida.

A visibilidade, no ecossistema digital, tem a ver com o alcance e a facilidade com que a informação disponibilizada é encontrada pelos utilizadores desta ambiência. Pode-se afirmar que ela é um dos principais caminhos para inserir a marca no cotidiano das pessoas, visto que cada vez mais o tempo investido nesse meio cresce e a presença digital da marca deve estar forta- 
lecida. Nesse processo, a imagem da marca ${ }^{1}$ exerce papel fundamental e o posicionamento da empresa, se bem resolvido, pode fazer a diferença.

O posicionamento da empresa é utilizado para construir uma imagem positiva da organização na mente do consumidor, a respeito dos valores e diferenciais que a empresa tem. Segundo Kotler (1999, p. 48) "posicionamento é o esforço de implantar o benefício chave e a diferenciação nas mentes dos clientes". Tendo isso em vista, as estratégias para evidenciar o posicionamento são uma maneira de reforçar o que foi planejado previamente.

Um exemplo de marca que vivencia a transição da comunicação mais tradicional para uma comunicação mais inserida no ecossistema digital, moldado por ações na ambiência digital é a Faber-Castell, que foi fundada em 1761 na Alemanha e está presente no Brasil desde 1931. Com sua imagem já consolidada, a organização busca se reinventar a todo o momento para se manter viva na lembrança do público. No contexto atual, com o crescimento da tecnologia, há muita informação disputando a atenção de um mesmo público, cabe à empresa compreender essa realidade e pensar suas ações estrategicamente para obter êxito. Entender o comportamento do consumidor e se adaptar às novas necessidades do mercado, é extremamente importante para uma marca sobreviver nesse ambiente.

Percebendo a visibilidade que as redes sociais proporcionam, observamos que a Faber-Castell Brasil canaliza seus esforços comunicacionais nessa plataforma e essa pode ser considerada uma maneira que a organização encontrou de acompanhar o processo de evolução do ambiente digital, usando o espaço para manter a marca inserida no contexto do consumidor. A empresa está presente nas mídias sociais: Facebook, Instagram, Youtube e também em um aplicativo chamado "Floresta sem fim", e entre essas mídias, a sua atuação tem maior ênfase no Facebook.

Com base nas considerações expostas, surgiu o seguinte problema de pesquisa: quais estratégias utilizadas no Facebook são capazes de ampliar a visibilidade da marca na ambiência digital? Partindo desta indagação, o objetivo geral do presente trabalho é analisar as estratégias comunicacionais que a marca Faber-Castell Brasil utiliza na rede social Facebook para ter visibilidade na ambiência digital. Para isso, será necessário identificar as es-

1 Imagem de marca para Kotler (2000, p. 318) "a identidade está relacionada com a maneira como uma empresa visa identificar e posicionar a si mesma e seus produtos. Entretanto, a imagem é a maneira como o público vê a empresa e seus produtos". 
tratégias que a Faber-Castell Brasil utiliza, a partir dos conceitos de Lupetti (2007), classificar como acontece a presença digital da marca no Facebook, verificar qual tipo de post gera mais engajamento e, ainda, descobrir se a Faber-Castell remete ao posicionamento "Sua companhia para toda vida" em suas postagens feitas na mídia social para gerar engajamento.

A Faber-Castell é uma empresa que tem sua imagem de marca já consolidada, com seus mais de 250 anos de história. Os produtos comercializados por ela, acompanham várias gerações das famílias brasileiras e estão associados a uma das melhores fases da vida: a infância, fase essa que abarca aprendizagem, conhecimentos e descobertas importantes sobre o mundo e sobre si mesmo. Uma marca com tantos anos de mercado, constrói uma trajetória interessante em muitos aspectos e desperta a curiosidade nas mais variadas áreas de conhecimento.

Por diversas vezes, a organização foi explorada para fins acadêmicos, porém com olhares voltados à área administrativa. Uma empresa que se mantém no mercado durante tanto tempo e em nível mundial como a Faber-Castell, merece estudos que procurem compreender as estratégias e ferramentas que a marca utiliza para estar sempre evoluindo e se adaptando junto com as tecnologias e seus consumidores. O enfoque deste trabaIho irá agregar uma perspectiva comunicacional aos trabalhos que já foram feitos sobre a marca.

A seguir, será contextualizada a ambiência digital e serão apresentados os conceitos de estratégia e posicionamento. Em seguida, serão abordadas a visibilidade e a presença digital, desde seu nível mínimo até focar no seu nível máximo, que é o engajamento. Na sequência, aspectos metodológicos explicam como o trabalho foi desenvolvido e, após isso, será apresentada a análise propriamente dita. Por fim, serão apresentadas as considerações finais da pesquisa.

\section{AMBIÊNCIA/ECOSSISTEMA DIGITAL}

A necessidade de comunicação sempre esteve presente na humanidade, pois, desde os tempos mais remotos, a informação já acontecia por meio de sons, símbolos, sinais e fala, até chegar à escrita. A busca por expressão das mais variadas formas é contínua, e os canais de comunicação acompanham esse processo. De acordo com Angeloni (2010, p.8), "algumas ferramentas inventadas pelo ser humano tiveram e têm como finalidade melhorar cada vez mais a comunicação entre os seres humanos", por exemplo, o telefone, 
a televisão, os meios de comunicação sem fio e a internet. Strutzel (2015, p. $\mathrm{XVI}$ ) afirma que:

[...] nos últimos quinze anos o mundo mudou muito mais do que nos cinquenta anos anteriores. Por mundo entenda-se a sociedade, a cultura, a tecnologia, os meios de comunicação, o relacionamento entre as pessoas, as relações de consumo e tudo mais que envolve as atividades humanas. E não se pode negar que a informática foi o estopim dessa grande revolução cultural que inaugurou o que os especialistas chamam de Era da Informação (STRUTZEL, 2015, p. XVI).

Angeloni (2010, p.3) explica que existem quatro principais ondas de mudança da sociedade, dentre elas, a era da informação e do conhecimento, que é responsável por $55 \%$ do valor do produto, "na era da informação e do conhecimento, quem fica com a maior parcela do valor final do produto, é quem cria a informação e o conhecimento", concluindo que $15 \%$ fica com a onda agrícola, de força de trabalho e 30\% com a onda industrial, o capital financeiro.

Já para Garry (1999), as etapas de evolução da comunicação se estruturam em fases: oral, do alfabeto, do manuscrito, da tipografia e da eletrônica, essa última fase, segundo Angeloni (2010, p. 10), traz consigo grandes mudanças: "com a convergência das tecnologias da informática, televisão e telecomunicações, surge o conceito de rede, que vem, mais uma vez, revolucionar a comunicação", como declara Strutzel (2015, p. XVII).

A internet comercial, que recém completou vinte anos de existência, é a mais nova dos meios de comunicação, entretanto ela teve um tempo de adesão e popularização significativamente menor do que outras mídias como cinema, rádio e TV, os quais demoraram algumas décadas para se consolidar. E isso não é nada. Mais do que se adequar à realidade cotidiana das pessoas, a internet em pouco tempo modificou profundamente a sociedade em geral. A maneira como buscamos informações, nos comunicamos, consumimos produtos e serviços, trabalhamos e acessamos entretenimento, mudou radicalmente nos últimos dez anos.

Esse avanço tecnológico tem uma, dentre várias de suas consequências, facilitar o dia a dia do homem. Um exemplo disso é a possibilidade de acesso das pessoas a um dispositivo com internet, conseguir ampliar a maneira que se expressa e também visualiza o que as outras pessoas e empresas comunicam, como afirma An- 
geloni (2010, p.10) "a comunicação rompe o tempo e o espaço e se transforma em tempo real", as informações se espalham rapidamente dentro do ambiente virtual e não reconhecem barreiras de tempo, nem de local (STRUTZEL, 2015, p. XVII).

Diante disso, a facilidade que a tecnologia proporciona, faz com que as empresas tenham a oportunidade de humanizar e aproximar as marcas dos consumidores, se fazendo presente e se inserindo no contexto do seu público. A mensagem e os esforços comunicacionais que uma empresa produz no offline, ou seja, nas mídias tradicionais como televisão e rádio, por exemplo, poderá ganhar força e visibilidade dentro da ambiência digital online. Se integradas, essas duas mídias potencializarão a imagem da organização e também a comunicação com seu público-alvo. Angeloni (2010) explica que vivemos na era da informação e do conhecimento, portanto, o que uma marca comunica no âmbito digital deve estar de acordo com toda sua comunicação. Quanto mais integrada a comunicação da marca nessas ambiências estiver, mais legitimidade e visibilidade digital a empresa terá, mas, para isso, é necessário ter estratégias bem definidas e alinhadas com os objetivos organizacionais.

\subsection{Estratégia}

O termo estratégia surge num contexto militar onde significava a habilidade que os generais tinham em conhecer os aspectos psicológicos e comportamentais dos seus soldados, mais tarde, várias áreas do conhecimento, como a administração, se apropriou da palavra trazendo para o mundo empresarial. Porter (2004, p. XXVI) acredita que "o desenvolvimento de uma estratégia competitiva é, em essência, o desenvolvimento de uma fórmula ampla para o modo como uma empresa competirá, quais deveriam ser as suas metas e quais as políticas necessárias para levar-se a cabo essas metas".

O fato é que a estratégia é um recurso que se expande e se aprimora de acordo com o contexto em que é inserida. Lupetti (2007, p. 89) define estratégia como "ações planejadas e executadas a partir da análise ambiental interna e externa, de análise dos pontos fortes e fracos da organização, das ameaças e das oportunidades do mercado (...)", a comunicação utiliza essa ferramenta para medir consequências, riscos e ganhos antes de implementar suas ações no mercado, seja com a intenção de aumento de venda, visibilidade e até mesmo melhorar ou manter a imagem da marca. É no momento de definição da estratégia, que se analisa quais caminhos e métodos mais 
adequados a empresa precisa seguir para que alcance seus objetivos e metas. Sempre levando em consideração o posicionamento da empresa e as associações que o público-alvo será capaz de identificar, a partir de suas vivências e conhecimentos pessoais adquiridos ao longo da vida.

Sendo esta etapa um estágio indispensável da comunicação, Kotler (2000, p. 85) afirma que "é mais importante adotar a estratégia correta do que buscar o lucro imediato", pois quando a estratégia é escolhida aleatoriamente, é possível que todo o esforço comunicativo da marca, inclusive seu posicionamento, fique prejudicado perdendo mercado e, consequentemente, lucro.

Lupetti (2007) classifica os tipos de estratégias como podendo ser de: informação, testemunho, comparação, humor, ofensiva, defesa, indiferenciada e de posicionamento. Pérez (2012) afirma que a estratégia deve ser algo indissociável da comunicação, ainda mais nos dias de hoje em que tudo acontece de forma muito rápida e se espalha facilmente nas redes sociais, obtendo inúmeras visualizações e necessitando que a marca dê respostas rápidas. Para melhor visualização das diferenças nos tipos de estratégias citadas por Lupetti (2012), elaboramos o quadro 01.

Quadro 01: Tipos e características das estratégias

\begin{tabular}{|c|l|}
\hline TIPO DE ESTRATÉGIA & \multicolumn{1}{c|}{ CARACTERÍSTICA } \\
\hline Informação & $\begin{array}{l}\text { Prioridade para as informações de um produto ou serviço da em- } \\
\text { presa. }\end{array}$ \\
\hline Testemunho & Dar credibilidade ao produto. \\
\hline Comparação & $\begin{array}{l}\text { Compara os atributos de um produto com aos do seus concor- } \\
\text { rentes. }\end{array}$ \\
\hline Humor & $\begin{array}{l}\text { Deve ser usada com cautela para não encobrir a informação nem } \\
\text { a persuasão da comunicação. }\end{array}$ \\
\hline Ofensiva & $\begin{array}{l}\text { Compreende o ataque ao concorrente, visando suas vulnerabil- } \\
\text { idades. }\end{array}$ \\
\hline Defesa & $\begin{array}{l}\text { É usada normalmente pelos líderes de mercado com grande } \\
\text { posição competitiva. }\end{array}$ \\
\hline Indiferenciada & $\begin{array}{l}\text { Recomendada para fixar marcas de empresas ou linhas de pro- } \\
\text { duto. }\end{array}$ \\
\hline Posicionamento / & Dependem dos objetivos de comunicação. \\
\hline
\end{tabular}

Fonte: Adaptado de: Lupetti (2012, p. 105)

A estratégia de informação para Lupetti (2012) é mais usada para produtos que estão sendo lançados no mercado, ou quando o produto 
sofrer alguma alteração em sua embalagem ou sua fórmula. E a estratégia de testemunho usa celebridades para conseguir mais credibilidade para o produto em sua propaganda. A estratégia de comparação não é muito usada no Brasil, essa estratégia deve ser cuidadosa para não denegrir a imagem do concorrente. Na estratégia de humor devem ser avaliados o público-alvo, os problemas a serem resolvidos pela propaganda e, ainda, o tipo de humor recorrido. Na estratégia ofensiva é necessário que se conheça muito bem as fraquezas do concorrente-alvo e suas potencialidades. Já a estratégia de defesa é usada por aqueles que já tem uma vantagem competitiva grande. A estratégia indiferenciada é usada quando uma marca não consegue diferenciar segmentos de mercado e público-alvo para seus produtos. Por fim, tem-se a estratégia de posicionamento/reposicionamento, que esclarece que as pessoas não compram produtos, e sim a solução para problemas, portanto pode-se considerar que essa estratégia busca diferenciar a marca na mente do consumidor.

Saad (2003) observa que a mensagem que as marcas estavam acostumadas a produzir para sua comunicação, com o avanço da tecnologia, se transforma em conteúdo e as empresas devem se preocupar e acompanhar esse processo para que as informações a respeito da marca não fiquem desencontradas nessa migração para o ambiente virtual.

\begin{abstract}
O que emerge como fundamental é encontrar a melhor forma de transformar essas mensagens em conteúdos adequados às características tecnológicas e de mercado do mundo digital. Como trabalhar essa transformação e manter ainda as características básicas de valores e credibilidade, mesmo que o conteúdo agregue à mensagem novos "adereços" como prestação de serviços, venda de arquivos, comércio eletrônico, entre outros (SAAD, 2003, p. 77)
\end{abstract}

Para assegurar que todo este processo de mudança no cenário da comunicação da marca não comprometa sua imagem, a estratégia de posicionamento é fundamental, pois será através dessa estratégia que a empresa conseguirá se manter em lugar de destaque na mente do consumidor. Neste contexto, Gabriel (2018) relata que as mudanças que a tecnologia trouxe impactam em três dimensões principais da vida humana: velocidade, volume e variedade. Isso também amplia o estresse e a distração das pessoas, o que exige que as marcas tenham um diferencial que restaure o foco, e aí é que está a importância de ter um posicionamento bem definido. 


\subsubsection{Posicionamento}

O posicionamento é utilizado para construir uma imagem positiva da marca na mente do consumidor, a respeito dos valores e diferenciais que a empresa tem. De acordo com Al Ries e Jack Trout (2002), o posicionamento deve ser algo relevante para o público-alvo e estar de acordo com as necessidades e desejos dos compradores. Segundo Kotler (1996, p. 270), "posicionamento é o ato de desenvolver a oferta e a imagem da empresa de forma que ocupem um lugar distinto e valorizado nas mentes dos consumidores", é a maneira que a marca tem de se destacar de seus concorrentes e é o ponto norteador para desenvolver toda a comunicação da marca: tipo de linguagem, meios, canais, estratégias e ações.

Com o avanço e com a evolução da tecnologia e das máquinas, os produtos acabaram se tornando muito parecidos e, com isso, surgiu o problema para as empresas em diferenciar sua marca e seus produtos em um universo de acirrada competição. Na ambiência digital, onde há muita informação disputando a atenção dos mesmos consumidores, torna-se ainda mais difícil conseguir destaque. Através do posicionamento, a marca pode encontrar a solução, pois essa é uma importante maneira de conseguir com que o consumidor repare na marca e a considere diante de tantas outras.

A imagem que a empresa quer criar na mente do consumidor nem sempre é tal qual a que o consumidor percebe, isso pode ocorrer por diversos motivos. Porém, o que a comunicação deve entender é que o posicionamento da empresa deve estar de acordo com o contexto do público-alvo, suas necessidades e seus desejos devem ser levados em conta na hora de construir a estratégia de posicionamento. Tudo interfere nesse processo, a forma de linguagem usada, o canal e o meio utilizado para veicular a mensagem, se é relevante para o público-alvo e, ainda, se faz parte do ambiente e do conhecimento do público.

Muitas vezes o que faz sentido em um país, pode ser julgado totalmente inadequado em outro, e a marca deve estar ciente de questões como essa na hora de desenvolver o seu posicionamento. Hoje, com o advento da internet, um conteúdo disponibilizado dentro ou fora da ambiência digital, pode ganhar proporções enormes e uma marca, mesmo que atue só em um determinado local, pode ser conhecida mundialmente através da rede. $\mathrm{O}$ posicionamento está intimamente ligado à segmentação do público-alvo da marca. Nessa senda, Lamb (2004, p. 206) explica que: 
[...] a segmentação de mercado tem um papel importante na estratégia de marketing de quase todas as organizações bem-sucedidas e é uma poderosa ferramenta de marketing, por diversas razões. A mais importante é que todos os mercados incluem grupos de pessoas ou organizações com diferentes necessidades e preferências de produtos. A segmentação de mercado ajuda os profissionais de marketing a definir mais precisamente as necessidades e desejos do consumidor. Devido ao fato de que os segmentos de mercado diferem de tamanho e potencial, a segmentação ajuda os tomadores de decisões a definir os objetivos de marketing de maneira mais precisa e a melhor alocar os recursos. Por sua vez, o desempenho pode ser mais bem-avaliado quando os objetivos são mais precisos (LAMB, 2004, p. 206).

Com o posicionamento e a segmentação bem resolvidos, ainda resta pensar em como conseguir visibilidade na ambiência digital, já que conseguir visibilidade nesse meio deve ser prioridade para as marcas que querem continuar no mercado.

\subsection{Visibilidade}

Antes da evolução das mídias sociais, a visibilidade significava enxergar até onde o olho alcançasse dentro do espaço em que o indivíduo estivesse fisicamente, como afirma Thompson (1998):

O desenvolvimento da mídia criou novas formas de publicidade que são bem diferentes da publicidade tradicional de co-presença. A característica fundamental destas novas formas é que, com extensão da disponibilidade oferecida pela mídia, a publicidade de indivíduos, ações ou eventos, não está mais limitada à partilha de um lugar comum. Ações e eventos podem se tornar públicos pela gravação e transmissão para outros fisicamente distantes do tempo e do espaço de suas ocorrências. (THOMPSON, 1998, p.114).

Com o crescimento alcançado pela comunicação, hoje já é possível ampliar o significado desta palavra, pois agora existem recursos que permitem a uma pessoa que esteja no Brasil, acompanhar ao vivo uma reunião que está acontecendo do outro lado do mundo, por exemplo, através de algum dispositivo eletrônico que esteja conectado. Dessa maneira, as marcas que adentram o âmbito digital, para disponibilizarem suas informações e conteúdo, devem estar cientes de que estas ficarão visíveis 24 horas por dia, todos os dias do ano, para qualquer pessoa ou empresa acessar no momento em que julgar 
mais adequado.

Segundo relatório da ONU divulgado em 2014, a população que tem acesso à internet, chegou a 3 bilhões de pessoas, cerca de $40 \%$ da população mundial, mesmo não sendo a realidade da maioria, ainda assim é um número expressivo. (FOLHA, 2014). No Brasil, uma pesquisa citada por Saraiva (2016), do Instituto Brasileiro de Geografia e Estatística (IBGE), revelou no ano de 2014 que o número de brasileiros com acesso à rede já era de 50\%. Ainda, dentro dessa nova realidade sobre a internet, um estudo realizado por uma empresa alemã que faz pesquisa de mercado, a Gesellschaft für Konsumforschung (GFK), identificou na pesquisa feita em 24 países, que $40 \%$ da população mundial fica conectada $24 \mathrm{~h}$ por dia (TECNOLOGIA, 2015). Dentro dessa realidade, as marcas e as empresas estão se adequando para a nova maneira de fazer e consumir a comunicação.

Na mesma lógica de pensamento de Thompson, Barichello (2004, p.47) afirma que "busca-se atingir as pessoas em função de sua exposição aos meios de comunicação e as organizações procuram utilizar os meios de comunicação para moldar a opinião pública de acordo com seus interesses". Por outro lado, sabe-se que apesar de todo o esforço das marcas para produzirem seu conteúdo e transmitir a mensagem de forma clara, a interpretação da informação é feita de uma forma totalmente subjetiva e pode variar de acordo com cada indivíduo, que recebe o conteúdo e se apropria da mensagem, dando sentido ou não para a mesma, de acordo com suas experiências, sentimentos e conhecimentos adquiridos ao longo de sua vida.

Solomon (2002 p.28) acredita que "duas pessoas podem ver ou escutar o mesmo acontecimento, mas a sua interpretação pode ser tão diferente como da noite para o dia, dependendo da forma como a mensagem chega aos seus cérebros e das suas expectativas em relação ao que iam ver ou ouvir". E os meios de comunicação atendem também à importante função de servir como plataforma para que as empresas possam explicar e justificar seus atos perante a sociedade. Processo esse que Barichello (2004, p.49) afirma ser a maneira pela qual uma empresa ou marca consegue sua legitimidade. Barichello (2004, p.21) explica que "podemos articular os conceitos de "legitimação" - entendida como o processo que engloba as práticas de explicação e justificação de uma instituição perante uma sociedade". A maneira como a empresa ou a marca interage com o público nesse espaço, tem papel fundamental no processo, fazendo com que as empresas se preocupem cada vez mais com a relação criada com seu público e procurando 
alcançar uma visibilidade maior dentro desse mundo tão vasto que é o digital, para estarem aptas a disputarem pela sua legitimidade.

A visibilidade pode ser uma forma de as marcas se promoverem, pois, sugere que a visibilidade alcançada, seja sinônimo de autenticidade. Barichello (2004, p.22) considera que:

\begin{abstract}
(...) é possível observar uma transferência da cena do processo de legitimação, que deixa de ser o local onde ocorrem as práticas institucionais e inclui, cada vez mais, a representação e justificação das mesmas nos meios de comunicação de massa. Os mídia são o principal dispositivo contemporâneo de visibilidade (...) sendo responsáveis, em grande parte, pela sua legitimação junto à sociedade. (BARICHELLO, 2004, p.22)
\end{abstract}

Podemos inferir, assim, que não é suficiente para as marcas se estabelecerem somente no espaço físico, mas igualmente importante se preocuparem com seu espaço conquistado através da visibilidade, dentro do contexto digital.

\title{
2.3 Presença digital
}

"A introdução de novos processos e tecnologias sempre provocou mudanças significativas nas relações entre o mercado e o consumidor" (TURCHI, 2018, p. 138). Foram vários estágios desde que o uso da internet se incorporou ao comportamento dos indivíduos e exigiu que as empresas se adaptassem para dar conta deste novo consumidor, que agora exige a presença das marcas no ecossistema digital.

Strutzel (2015 p.87) define presença digital como "o conteúdo online produzido e distribuído pela entidade e a criação de pontos de contato com a audiência". A presença digital de uma empresa, se bem trabalhada, se torna uma eficaz ferramenta de comunicação auxiliando a marca para um avanço com o engajamento do público.

Uma marca tem presença digital quando seu conteúdo é relevante para o público-alvo. Permanecer atuante no meio e manter o posicionamento da marca alinhado ao conteúdo que está veiculado no digital e no offline, é um caminho para se conseguir a presença digital.

Ainda, para Strutzel (2015, p.XIX), "não possuir uma Presença Digital é sinônimo de não existir na internet. E o público em geral já se habituou tanto a ela que desenvolveu a percepção de que se algo não existe na web, também não existe no mundo físico". Pode-se entender, que não basta somente 
ter uma página da empresa na internet, mas sim desenvolver conteúdo relevante para se conseguir destaque e conquistar um espaço importante na mente do consumidor. É através desse canal que na contemporaneidade, antes de consumir, as pessoas buscam por informações a respeito das marcas e o conteúdo ali disponibilizado pela empresa, avaliações e comentários realizados por outros consumidores, acabam exercendo influência na decisão de compra dos consumidores em potencial.

Por esse motivo, as marcas devem se preocupar cada vez mais sobre o que produzem para divulgar na rede e reconhecer o papel importante que esse novo meio de comunicação exerce na atualidade. Para uma presença digital sólida, é importante que se desenvolva um plano de marketing digital que atenda a questões, como os autores Strutzel (2013), Wolcow (2015) e Leite (2016) elencam sendo quatro pilares: posicionamento, conteúdo, relacionamento e monitoramento. Tudo isso está interligado e objetiva uma presença digital competente.

Turchi (2018, p. 231) explica que "a tecnologia vem transformando a vida, o mundo e os negócios de maneira profunda e irreversível", sendo assim, as organizações são colocadas em contato com novos desafios, mas também com novas oportunidades a todo momento. Isso acontece, porque na internet as informações chegam e passam muito rápido e o consumidor também muda seus interesses e opiniões com muita velocidade. Strutzel (2015, p. XIX) afirma que "a partir da interação entre os indivíduos nestas plataformas de redes sociais, outras tecnologias paralelas foram impulsionadas e a adesão cresceu exponencialmente", por isso, a forte presença digital permite às empresas que acompanhem o comportamento do seu público mais de perto, através do relacionamento que se constrói por meio das interações, reações, comentários e engajamento com que o público responde para as marcas na rede.

Strutzel (2015) aponta que as fases da presença digital acontecem em quatro momentos: a primeira trata da existência, que é o reconhecimento por parte da empresa, de estar dentro da internet e adotar a cultura digital, a existência somada ao planejamento é o caminho. A segunda etapa é a da atração, que diz respeito aos pontos de contatos estabelecidos e à produção de conteúdo que deve levar em conta a frequência, relevância, equilíbrio e qualidade. A terceira fase é o relacionamento, que é o acompanhamento que a marca faz para saber como o público reage ao seu conteúdo. Já a quarta e última fase é a do engajamento, que de acordo com Strutzel (2015), 
é o nível máximo de relacionamento do público com a marca.

\subsubsection{Engajamento}

Sobre engajamento, Strutzel (2015) acredita que essa é a fase em que o público acompanha ativamente o conteúdo publicado pela marca. $O$ engajamento é resultado do empenho da comunicação da marca para obter este nível de relação com o público-alvo. Significa que o conteúdo produzido pela empresa é relevante para o consumidor conseguir a atenção e alguma resposta do público através de visualização, curtida, comentário e compartilhamento, ou seja, é sinônimo de que a marca está no caminho certo. Cerqueira e Silva (2011, p. 113) definem que engajamento são as "interações repetidas que fortalecem o investimento emocional, psicológico ou físico que um consumidor tem de uma marca". Diante disso, pode-se compreender que o engajamento está intimamente ligado ao envolvimento que a marca recebe por parte do público-alvo, e à relação que a empresa está construindo com seus consumidores.

"A diminuição no engajamento afeta principalmente os relacionamentos que, para se desenvolverem, requerem atenção e foco" (GABRIEL, 2018, p. 102). No entanto, o nível de engajamento pode variar. Segundo propõe Li (2011, p. 81), os níveis são organizados em uma pirâmide que "apresenta as formas e os comportamentos específicos de engajamento". O primeiro nível, na concepção de Li (2011), é o de observação, onde os internautas recebem, visualizam e acompanham o conteúdo que a marca oferece e disponibiliza na internet. Dependendo do quão relevante o observador concluiu que o material da marca é, partirá ou não para o segundo nível, que é o compartilhamento. Os compartilhadores são as pessoas que realizam a ação e afirmam, através do ato, que concordam com aquele conteúdo ou mensagem. Isso acontece não somente quando o internauta compartilha um conteúdo produzido pela própria marca, mas, também, quando faz alguma atualização de perfil profissional ou publica fotografias ligadas ou relacionadas à marca. Quando o consumidor compartilha uma publicação, é conotada a ideia de que ele considera aquela informação digna de ser dividida com seus amigos online.

Os comentários também são importantes métodos para saber o nível de contentamento do público com a marca, sendo os comentaristas, o próximo nível depois dos compartilhadores. Neste nível, o consumidor opina sua experiência e exibe seu grau de satisfação com o que a marca está oferecendo. 
Li (2011, p. 82) aponta que nos comentários o consumidor está "compartiIhando ativamente sua própria opinião e fazendo isso no contexto de uma conversa já existente". Os comentários de avaliação dos produtos e serviços são uma importante fonte para novos e possíveis consumidores, pois esses apresentam informações de pessoas reais que já tiveram alguma experiência com aquilo que se busca.

Figura 01: Pirâmide do engajamento

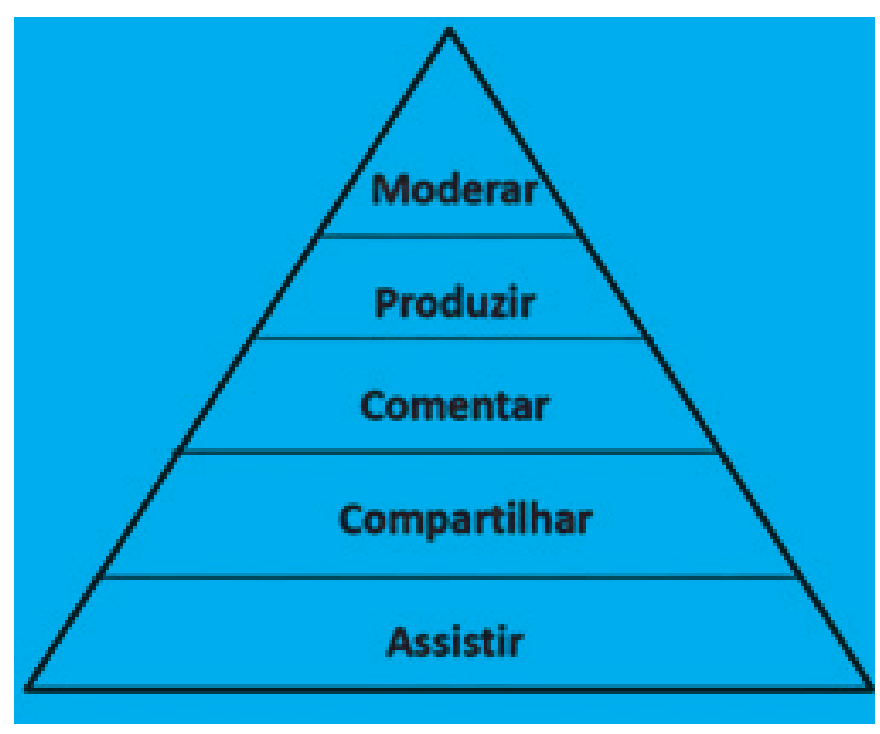

Fonte: Li (2011, p. 81)

O nível dos produtores, segundo Li (2011), é quando os próprios consumidores criam conteúdos para divulgar em suas redes sociais. A Walmart, por exemplo, conseguiu com que mães engajadas, desenvolvessem conteúdos e mantivessem um blog atualizado falando sobre a marca. Isso gera uma relação mais sólida dos consumidores com a empresa e possibilita que a organização saiba o que o consumidor está buscando (BETHANY, 2017).

Na ponta da pirâmide, pode-se observar que está o nível denominado “moderar". Esse estágio torna-se mais estratégico, pois dentro da comunidade, são eleitos alguns representantes para levar até a marca informações a respeito dos desejos e necessidades do público-alvo. A empresa deve ver essas pessoas como conselheiros confiáveis.

Estudando a pirâmide do engajamento e suas divisões, é possível entender melhor o funcionamento da interação do público com as marcas nas redes sociais e, assim, estabelecer a estratégia mais adequada para a empresa nesta ambiência. 


\subsubsection{Presença na ambiência digital - Facebook}

A ambiência digital é, para a comunicação das marcas, uma grande oportunidade para se promover, se tornar conhecido para seu público-alvo e, ainda, estar inserido no contexto atual e na realidade de muitas pessoas, além de poder acompanhar de perto as ações dos concorrentes. Foi na ambiência digital que as pessoas descobriram um novo jeito de se comunicar, de consumir informação, conhecimento, produtos e serviços. De acordo com Strutzel (2015, p. XVII),

No mundo inteiro um contingente imenso de pessoas tem contato com a internet desde o momento em que acorda até a hora de ir dormir (...) E o relacionamento entre pessoas foi totalmente revolucionado pelos ambientes das redes sociais. E foi justamente neste ponto em que se intensificou a curva de crescimento das mudanças sociais.

Esta é a nova realidade das pessoas e as marcas, que querem acompanhar essa etapa da evolução da sociedade, devem procurar entender como essa plataforma funciona e buscar meios de se adequar ao ambiente para usar as possibilidades que ela oferece a favor de sua marca. As redes sociais exercem papel fundamental na ambiência digital, um grande exemplo disso é o Facebook, que surgiu em 2004, criado por estudantes americanos da universidade de Harvard, com a intenção de servir para pessoas encontrarem relacionamentos amorosos. Naquela época, essa rede social era disponibilizada apenas para os estudantes da instituição, hoje é utilizada para outras milhares de finalidades, se espalhou pelo mundo inteiro já chegou a 127 milhões de usuários no Brasil, sendo que conta com mais de 2,2 bilhões de usuários distribuídos no mundo (VALENTE, 2018).

O Facebook permite que os usuários criem seu perfil pessoal ou, no caso de empresas, uma página de fãs onde o dono da conta tem acesso a ferramentas de estatísticas das postagens e ainda elaborem enquetes e discussões, funções que não estão disponíveis para os perfis. As formas de conteúdo que a plataforma da rede social Facebook aceita são vídeos, imagens, links e textos.

Dentre essas opções, o que mais gera engajamento, segundo um estudo da Adobe, são as imagens, que tem um forte apelo junto aos internautas da rede. Essa estratégia se torna uma aliada na hora de reforçar o posi- 
cionamento da marca e o ideal é que as postagens explicitem estas ações (ADOBE, 2015). Apesar da imagem ter sido apontada na pesquisa como a detentora do engajamento, uma variante que deve ser observada sobre esse tema é o contexto, o momento certo de uma postagem, independente da sua forma, pode gerar mais engajamento que uma postagem de imagem. Há publicações que são feitas para aproveitar alguma situação incomum do dia a dia e por consequência geram muitas respostas por parte dos internautas. Sendo assim, existem diversos tipos de postagens que são feitas com o intuito de provocar comentários, induzir os cliques, mas o conteúdo é o que mais importa na busca por engajamento e interação com o público.

\section{METODOLOGIA}

A presente pesquisa é qualitativa e quantitativa. Na visão de Michel (2009, p.39), esse tipo de pesquisa "quantifica e percentualiza opiniões, submetendo seus resultados a uma análise crítica qualitativa. Isso permite levantar atitudes, ponto de vista, preferências que as pessoas têm a respeito dos determinados assuntos". A partir desse entendimento, foi possível conseguir uma visão mais ampla sobre quem interage com a marca e que tipo de postagem conseguiu mais engajamento. Para isso, foi realizada uma análise de conteúdo, a fim de obter uma melhor compreensão dessas informações, que, de acordo com Bardin (1977, p. 40), "visa obter, por procedimentos, sistemáticos e objetivos de descrição do conteúdo das mensagens, indicadores e conhecimentos relativos às condições de variáveis inferidas na mensagem".

Bardin (1977) também define a análise de conteúdo como sendo uma técnica de pesquisa que objetiva a descrição do conteúdo da comunicação de forma, também, quantitativa. Diante disso, a análise de conteúdo requer por parte do pesquisador, atenção, dedicação, paciência, empenho e um olhar interpretativo para análise dos dados coletados através desse método.

O autor Bardin (1977) apresenta um esquema de etapas para análise de conteúdo que se organizam basicamente em três momentos: o primeiro, uma pré-análise onde acontece uma sistematização das ideias iniciais, exige uma leitura fluente para começar a conhecer o texto e depois a escolha do material para análise, formulação de hipóteses e objetivos e elaboração dos indicadores. O segundo momento é a exploração do material, definição de categorias, unidades de registro e das unidades de contexto, além da etapa 
de descrição analítica. Por fim, o terceiro momento, é o tratamento dos resultados, inferência e interpretação, onde ocorre a análise reflexiva e crítica dos resultados obtidos.

Para melhor organizar as análises, foram elaborados dois quadros com categorias para classificar as postagens da marca. O quadro 02, a seguir, ilustra os critérios para investigar a produção de conteúdo.

Quadro 02: Critérios para a análise da produção de conteúdo da marca

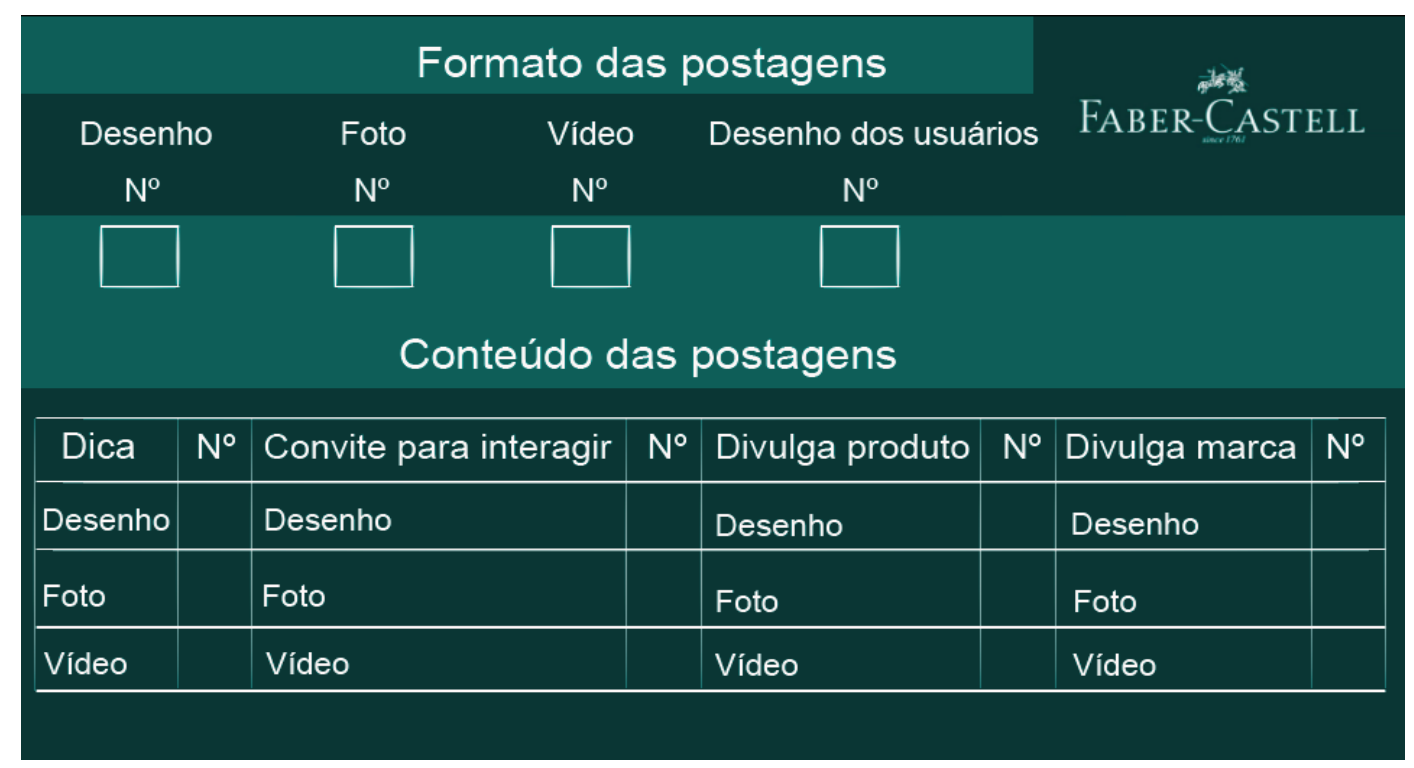

Fonte: elaboração própria

Chizzotti (2006, p. 98), explica que "o objetivo da análise de conteúdo é compreender criticamente o sentido das comunicações, seu conteúdo manifesto ou latente, as significações explícitas ou ocultas". Durante a análise foi possível perceber as informações mais evidentes e, também, as mais subjetivas, como o posicionamento da empresa, por exemplo. Através da análise das interações dos internautas com os conteúdos da marca, foi possível identificar muitas características do público-alvo. Também utilizamos o Quadro 03, que foi criado com os critérios para observação das reações dos usuários às postagens da empresa. 
Quadro 03: Critérios² para a análise da recepção de conteúdo da marca

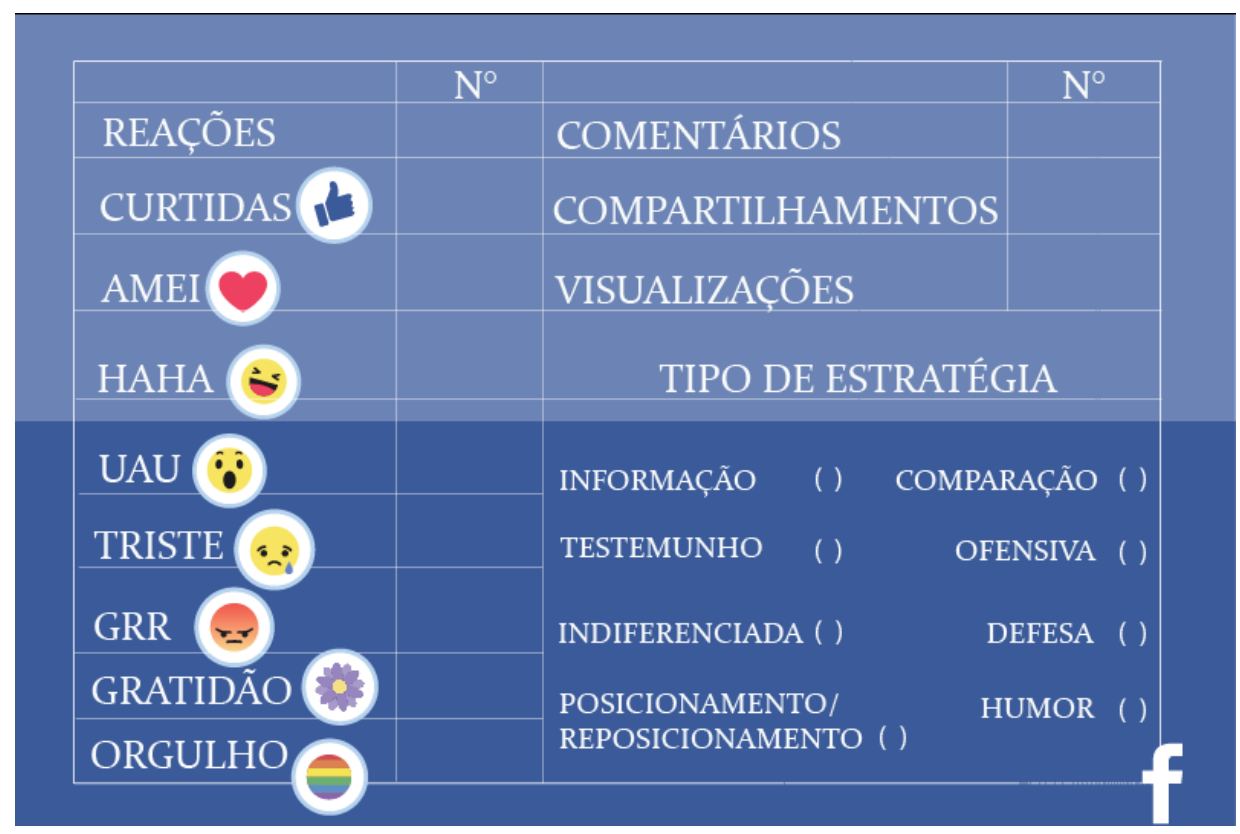

Fonte: elaboração própria

As reações foram contabilizadas primeiro por um número total das reações e, em seguida, especificadas por cada tipo de reação. Comentários, compartilhamentos e visualizações também contabilizadas e, por fim, o tipo de estratégia de comunicação observado.

\section{ESTRATÉGIAS COMUNICACIONAIS DA MARCA FABER-CASTELL NA AMBIÊNCIA DIGITAL}

A Faber-Castell foi fundada por Kaspar Faber em 1761 na Alemanha comercializando apenas lápis. A empresa expandiu seu repertório e oferece ao mercado do segmento de papelaria e escrita, produtos como lápis, lapiseiras, canetas, borrachas e kits educativos, além de comercializar em alguns países produtos cosméticos. Em 2011, a marca completou 250 anos, um grande orgulho para a família Faber, que administra a empresa há oito gerações. Segundo informações retiradas do site da organização, ela está presente em 120 países e conta com 7000 colaboradores em 14 fábricas pelo mundo. Seu principal produto são os lápis pretos e coloridos, a capacidade de produção mundial é superior a 2 bilhões de lápis de madeira por ano, o que faz da Faber-Castell a maior fabricante de lápis do mundo (FABER CASTELL, 
2017, online).

No Brasil, a Faber-Castell está presente desde meados de 1931, no interior da cidade de São Paulo, com uma produção anual de 1,9 bilhão de EcoLápis de madeira plantada, o que torna o Brasil líder mundial no setor. Seus esforços para a comunicação com os brasileiros estão concentrados no ambiente virtual, em redes sociais como Facebook e Instagram, contando também com um canal no Youtube e aplicativos. O Quadro 4, a seguir, resume a participação da Faber-Castell na ambiência digital em cada uma das plataformas utilizadas.

Quadro 04: Inserções da Faber-Castell na ambiência digital no Brasil

\begin{tabular}{|c|c|c|}
\hline INSERÇÕES & ENDEREÇO & O QUE É \\
\hline Instagram & $\begin{array}{l}<\text { https://www.instagram.com/ } \\
\text { faber_castell_br/> }\end{array}$ & Mídia social \\
\hline $\begin{array}{l}\text { Aplicativo } \\
\text { Pequenos } \\
\text { Criativos }\end{array}$ & $\begin{array}{l}<\text { https://itunes.apple.com/ } \\
\text { br/app/pequenos-criativos/ } \\
\text { id1095821550?mt=8> }\end{array}$ & $\begin{array}{l}\text { Plataforma para pais e re- } \\
\text { sponsáveis compartilharem e co- } \\
\text { mentarem desenhos e criações } \\
\text { das crianças. }\end{array}$ \\
\hline $\begin{array}{l}\text { Aplicativo } \\
\text { Floresta sem } \\
\text { Fim }\end{array}$ & $\begin{array}{l}\text { <https://itunes.apple.com/ } \\
\text { br/app/floresta-sem-fim/ } \\
\text { id1189326411?mt=8> }\end{array}$ & $\begin{array}{l}\text { O app traz vida ao Ecolápis na } \\
\text { forma de animais incríveis. Basta } \\
\text { apontar o celular para a caixa de } \\
\text { Ecolápis Faber-Castell e seguir as } \\
\text { instruções. Os lápis se transfor- } \\
\text { mam em lindos animais da fauna } \\
\text { brasileira. Cada cor de lápis se } \\
\text { transforma num bicho diferente. }\end{array}$ \\
\hline $\begin{array}{l}\text { Canal no } \\
\text { Youtube } \\
\end{array}$ & $\begin{array}{l}<\text { https://www.youtube.com/user/ } \\
\text { FaberCastellOficial }>\end{array}$ & Canal para compartilhar vídeos. \\
\hline Site Inspirarte & <https://www.inspirarte.art.br/> & $\begin{array}{l}\text { Plataforma digital para compar- } \\
\text { tilhamento de trabalhos artístico } \\
\text { de desenho. }\end{array}$ \\
\hline
\end{tabular}

Fonte: elaboração própria

Apesar da inserção da Faber-Castell na ambiência digital no Brasil ser sortida, para esta pesquisa, foi feita uma delimitação: apenas a página de fãs da marca Faber-Castell Brasil, na rede social Facebook, com análise das postagens realizadas durante os meses de junho e julho de 2017.

Vale informar que em sua página no Facebook, a Faber-Castell Brasil contava em maio de 2017, com 2.232.315 curtidas e 2.222.262 seguidores da página. Este canal é o mais utilizado pela marca e é por meio deste, que a empresa 
faz sua divulgação e, também, abre espaço para o público exibir trabalhos realizados com produtos da marca.

\subsection{Resultados e discussões}

A partir da observação do corpus, que incluiu 41 postagens, foi constatado que a maioria tratou da divulgação de produtos da marca aliada à arte do desenho. A estratégia comunicacional que prevaleceu foi a de informação, onde os conteúdos dos textos das postagens, eram de dicas relacionadas ao melhor uso dos itens, técnicas de ilustração e sugestões de entretenimento para as crianças, como a massinha de modelar da Faber-Castell.

Entre as publicações que obtiveram mais engajamento com o público, estão as que a marca convida os usuários a mostrarem seus desenhos por meio dos comentários. O posicionamento não fica explícito em texto, mas através da comunicação geral da empresa na rede social, que se dirige ao público adulto, reforçando a mensagem de que a Faber-Castell não é apenas uma empresa voltada para crianças em fase escolar, mas também para aqueles que, de forma amadora ou profissional, fazem uso dos artigos que a organização fabrica.

Durante os dois meses analisados, a página publicou o total de 41 posts com formatos diversos, divididos em fotos, desenhos e vídeos. Todas as postagens obtiveram reações, comentários, respostas da Faber-Castell e compartilhamentos. As publicações com menor número de interações, por parte do público, foram as fotos de capa que a marca atualizou em cada mês.

Gráfico 01: Análise em porcentagem sobre os formatos das postagens da marca

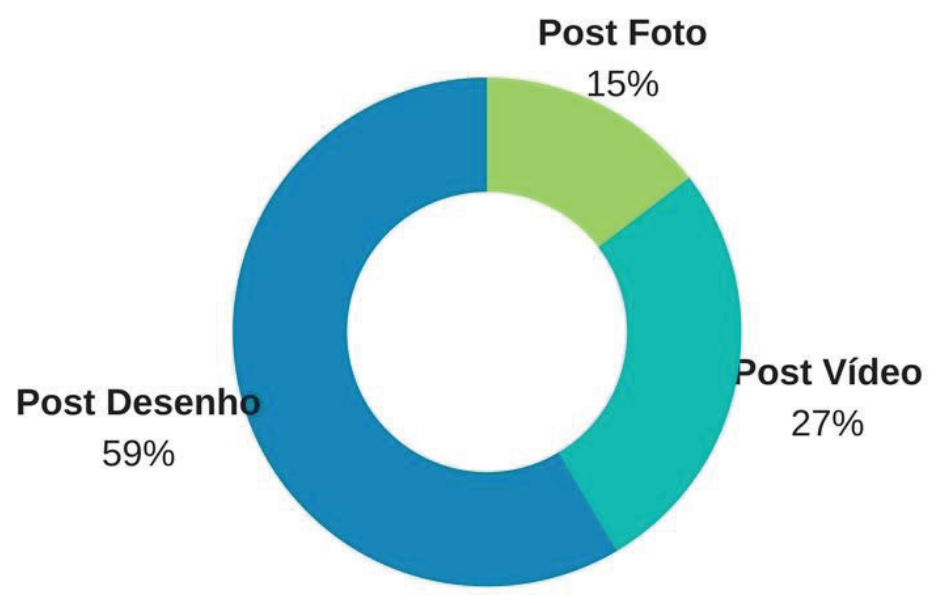

Fonte: elaboração própria 
O Gráfico 01, traduz a análise que foi realizada para descobrir qual formato a marca mais recorreu para fazer suas publicações. Pode-se constatar que a postagem com a inserção de desenho foi a mais utilizada, com $59 \%$, seguida por vídeos (27\%) e fotografias (15\%).

Não foi identificado um padrão específico quanto aos dias para postar conteúdo, visto que a marca publicou em geral a cada dois dias e algumas vezes mais de um post no mesmo dia. Apesar da Faber-Castell estar presente em outras plataformas já citadas neste trabalho, a empresa usou apenas o Facebook para divulgar o site Inspirart ${ }^{3}$ e o site do Programa Nacional de Reciclagem de Instrumentos de Escrita Faber-Castell ${ }^{4}$, para descarte de produtos. Os posts são sempre acompanhados de legenda e, às vezes, com hiperlinks redirecionando o usuário para os dois sites citados.

Foi possível perceber que a marca mantém na sua comunicação, a conexão com o segmento dos produtos que comercializa, os quais são relacionados à escrita. Essa associação é feita por meio da arte do desenho que a empresa optou por ser o principal formato de suas publicações na rede social. Este modelo de post, correspondeu a $59 \%$ do total de todas as postagens coletadas e analisadas no período de dois meses.

No Gráfico 02, a seguir, estão representados os formatos encontrados nas publicações e suas respectivas porcentagens.

3 Inspirart é uma plataforma online com dicas e técnicas de desenho, além dos usuários cadastrados poderem expor seus trabalhos e compartilhar nas redes sociais.

4 Em 2012, a Faber-Castell estabeleceu uma parceria com a TerraCycle e lançou um programa de coleta que permite a transformação de instrumentos de escrita em matéria prima reciclada, que substitui o material virgem que seria utilizado e evita o descarte de resíduos no meio ambiente. 
Gráfico 02: Análise em porcentagem dos tipos de postagens da marca

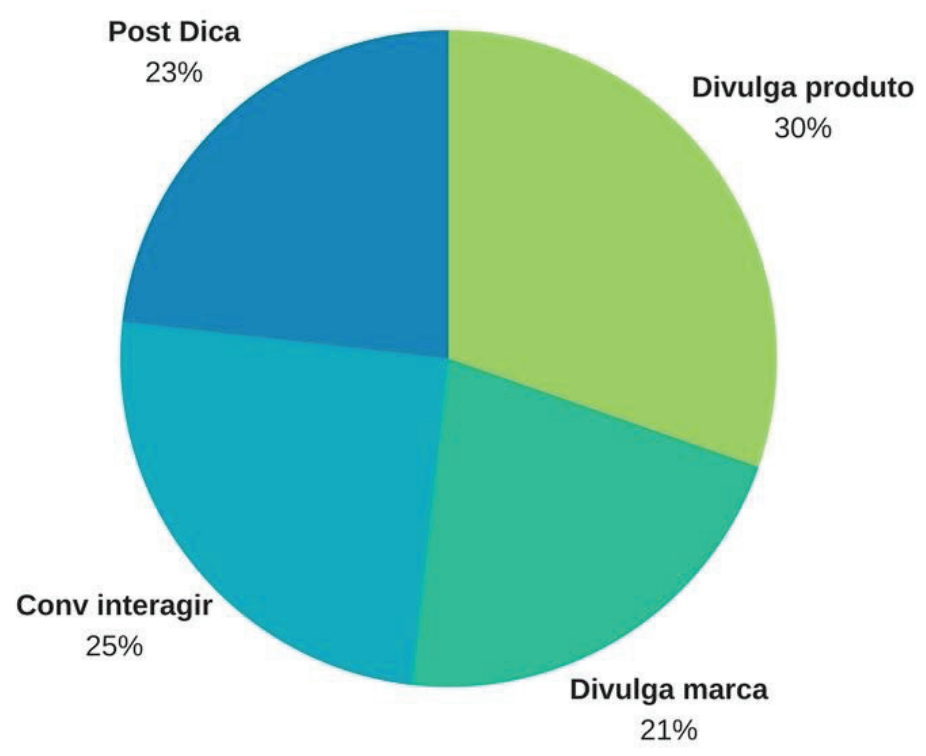

Fonte: elaboração própria

A partir do gráfico, observa-se que as postagens que divulgavam produtos representou a maioria das publicações, porém a marca não utiliza preço, mas sim ressalta a qualidade e especificações dos artigos.

O Quadro 05, abaixo, exibe a quantidade de postagens e sua distribuição dentro de cada categoria observada.

Quadro 05: Resultado5 da análise sobre a produção de conteúdo da marca

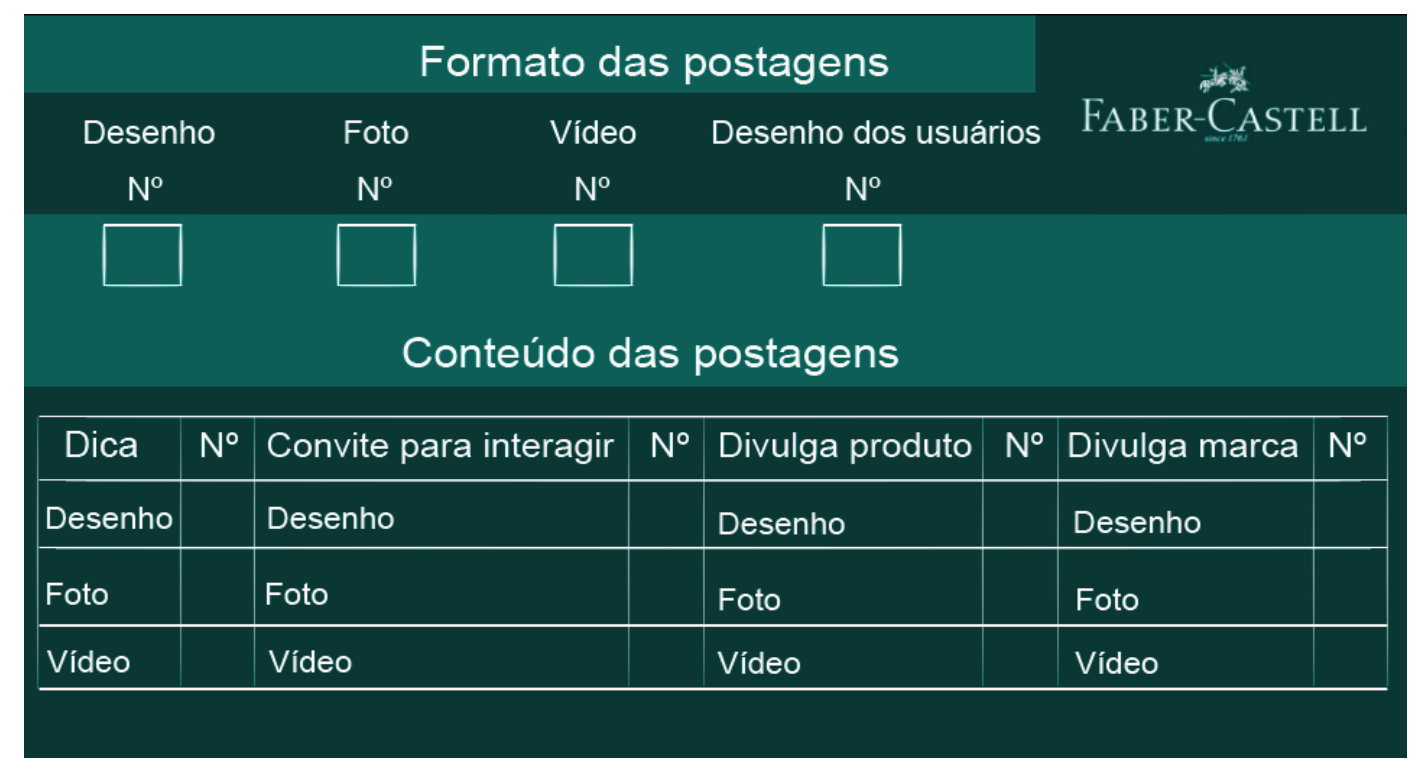

Fonte: elaboração própria

5 Quadro 05: Resultado da análise sobre a produção de conteúdo da marca 
O modelo de postagem mais utilizado pela marca foi com formato de desenho (veja Figura 02), com um total de 24 publicações e a maioria delas divulgando produtos. Nessas publicações normalmente a marca convida o usuário a interagir.

Figura 02: Postagem dica

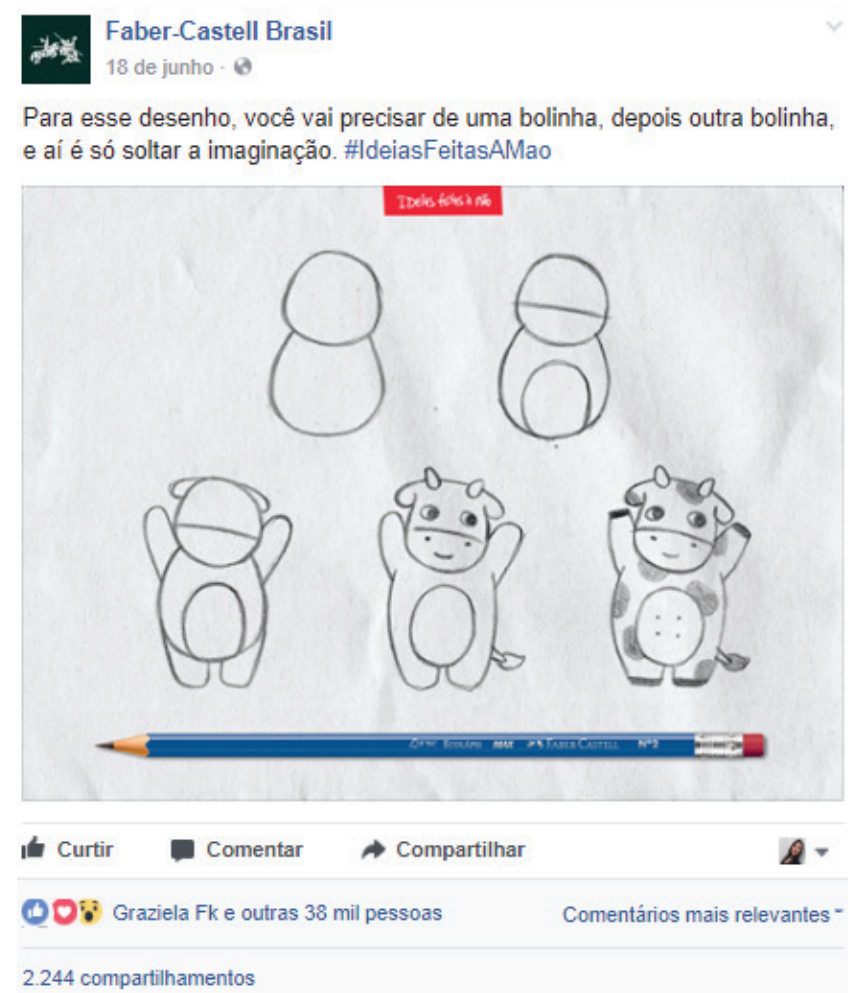

Fonte: Disponível em: <https://www.facebook.com/fabercastellbrasil/?ref=br_rs $>$. Acesso em: 18 jun. 2017.

Foi possível observar que essa estratégia traz resultados positivos para a marca, que recebeu nesse post 38 mil reações, 32 mil curtidas, 5,1 mil amei, 161 haha, 586 uau, 2 triste, 6 grr e 51 orgulho. Portanto, verifica-se que a estratégia de informação aparece novamente.

Segundo os ensinamentos de Li (2011), na pirâmide do engajamento a marca consegue alcançar todos os níveis, pois os usuários recebem o conteúdo que a empresa produz, assistem, compartilham, comentam e também produzem conteúdo. A estratégia de informação está presente em todas as postagens, revelando que a marca se preocupa em fornecer conteúdo relevante para seu público, o resultado é o engajamento de forma espontânea em sua rede social.

A Figura 03, a seguir, ilustra a postagem mais comentada do período da 
coleta de material. Em texto, a legenda sugere: "Quer ver corações? Escreva xoxo nos comentários".

Figura 03: Postagem dica

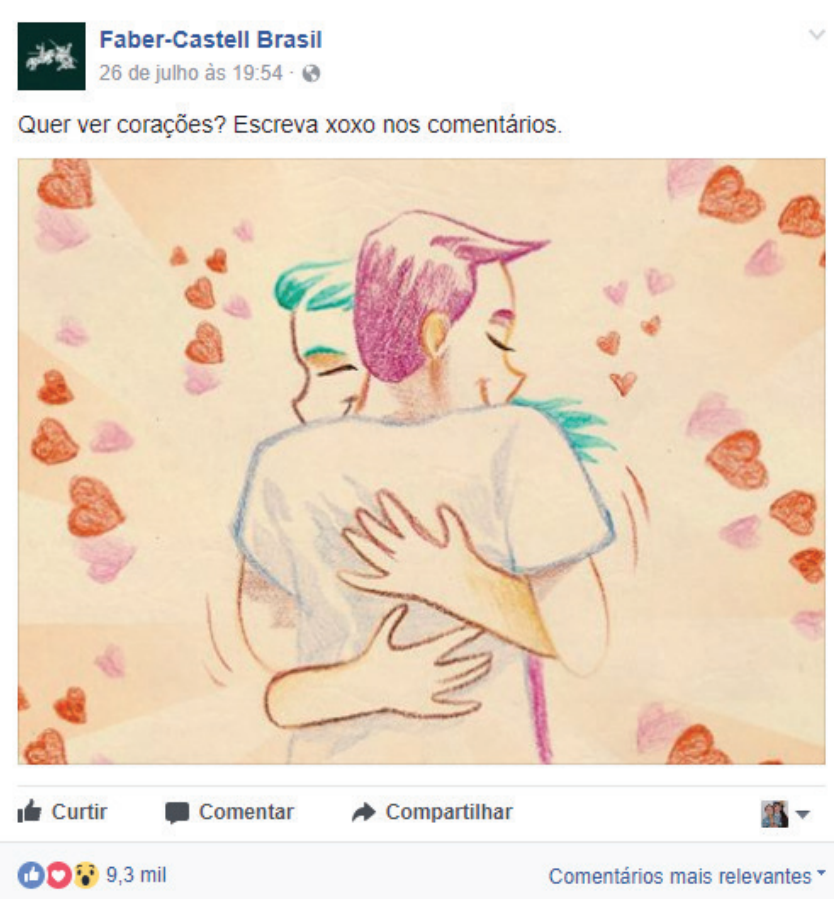

Fonte: Disponível em: <https://www.facebook.com/fabercastellbrasil/?ref=br_rs >. Acesso em: 26 jul. 2017.

A legenda da postagem conta com um texto curto e direto, mas suficiente para motivar a participação e ampliar o nível de engajamento dos usuários com a publicação. Observamos que os fãs da página interagem em todos os posts da marca, porém quando esta interação é solicitada, o número de interações é bem maior. Esta constatação está de acordo com os ensinamentos de Strutzel (2015), pois as chamadas para a ação são um meio eficiente para gerar engajamento nas mídias sociais, além de auxiliar e acionar a alavanca que faz com que o usuário participe.

Vale informar que a Figura 04 alcançou 12.454 comentários, as reações obtidas foram 9,3 mil com 7,5 mil curtidas, 1,7 mil amei, 30 haha, 72 uau, 3 triste e 21 grr. E a estratégia comunicacional usada foi a de informação, que, segundo Lupetti (2012), prioriza as informações de um produto ou serviço da empresa. Apesar de não estar sendo anunciado nenhum produto, a marca informa sobre um mecanismo de interação possível na publicação.

Já a publicação do dia 07 de junho de 2017, trazia como legenda um texto explicativo sobre os desenhos que os usuários enviaram diretamente para a 
fanpage e também por meio de hashtags no Instagram. E no dia 03 de junho de 2017, a postagem divulgava um produto, mais especificamente a canetinha carimbo Mini Duo.

Figura 04: Análise de postagem que divulga produto

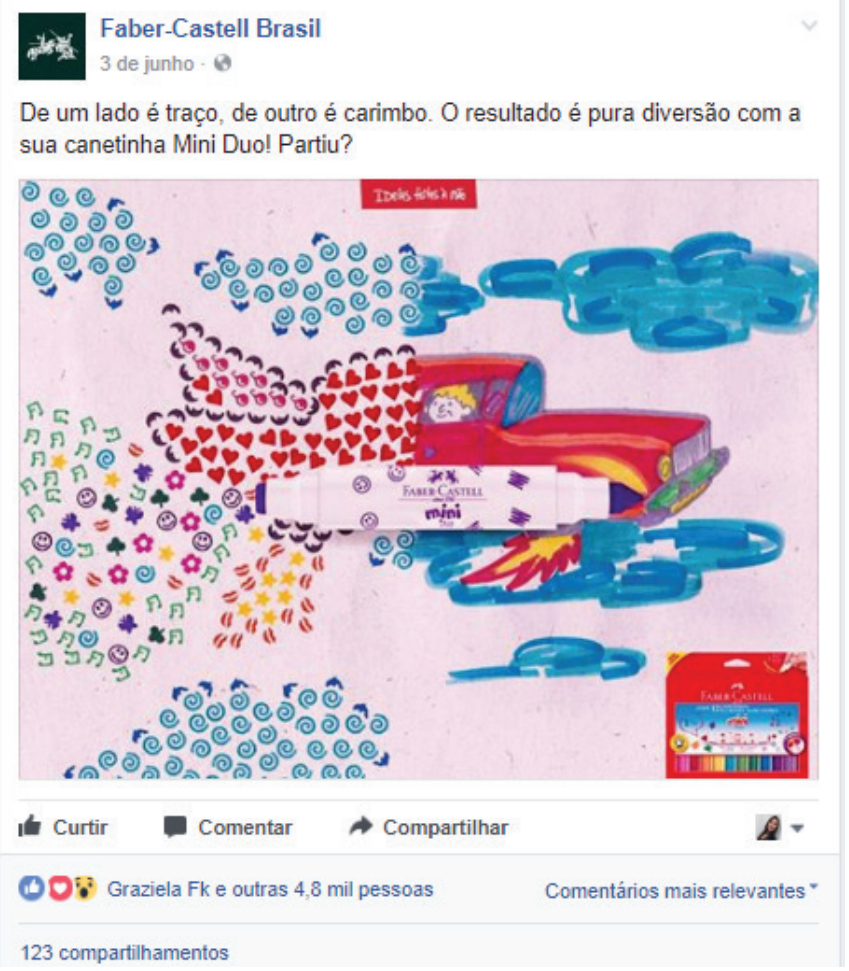

Fonte: Disponível em: <https://www.facebook.com/fabercastellbrasil/?ref=br_rs >. Acesso em: 03 jun. 2017.

Como todas as postagens desse tipo, a empresa não apresentou preços, mas sim as qualidades e características do produto anunciado de forma criativa e atrativa. Com uma ilustração bem colorida, a postagem recebeu 4,8 mil reações, 4,4 mil curtidas, 347 amei, 10 haha, 53 uau e 2 triste. Sendo a estratégia de informação observada, o conteúdo da publicação de produto informa sobre as infinitas possibilidades que o item pode fazer, dependendo apenas da imaginação do consumidor.

Outra estratégia foi utilizada no dia 12 de junho, quando a marca postou um vídeo de 2 minutos, que contava através da narração e do desenho, a trajetória de vida do criador do lápis da empresa, Lothar von Faber, e todo o cuidado que ele tinha em relação aos materiais utilizados na formulação do lápis. 
Figura 05: Postagem que divulga a marca

(1)

Faber-Castell Brasil

12 de junho - 0

Você já parou para pensar sobre a história do lápis que você usa hoje? Pois

saiba que ela começou lá atrás com um cara chamado Lothar von Faber.

Assista ao vídeo e conheça a incrível trajetória desse visionário.

\#ideiasfeitasamao
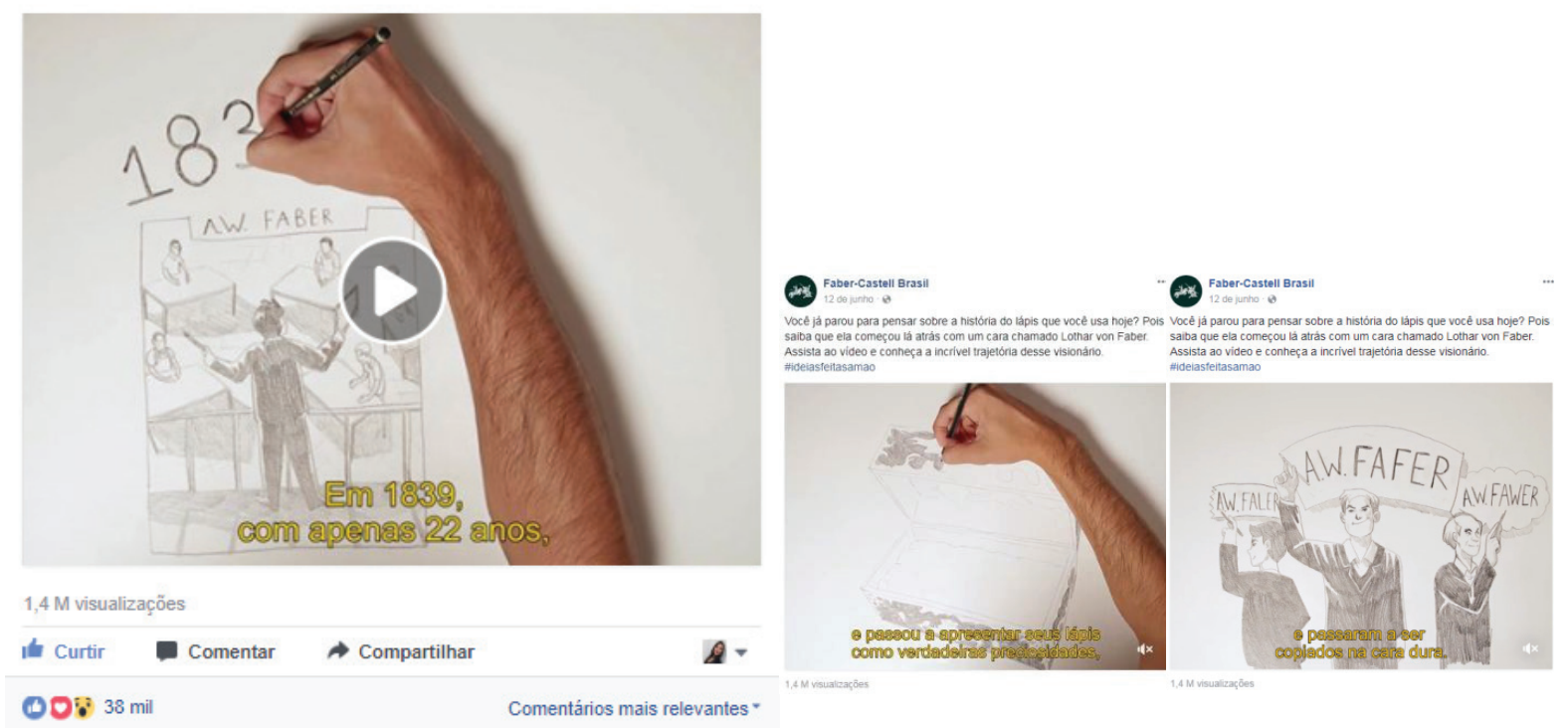

Fonte: Disponível em: <https://www.facebook.com/fabercastellbrasil/?ref=br_rs $>$. Acesso em: 12 jun. 2017.

O conteúdo dos vídeos postados é sempre sobre dicas e técnicas de desenho. Esse post retratava a história do lápis da marca e recebeu 38 mil reações, sendo 28 mil curtidas, 8,1 mil amei, 127 haha, 2 mil uau, 13 triste, 9 grr e 310 orgulho. Aliado à estratégia de informação, foi acrescida nessa postagem, a estratégia de posicionamento, o vídeo mostra um lado humano por trás da marca e exibe a trajetória de uma figura importante na criação da organização. A recepção dos vídeos, em geral, e neste caso específico, obtém um número alto de interações, mais que em postagens estáticas como fotos e desenhos.

A estratégia de posicionamento ajuda a criar uma imagem positiva da marca na mente dos consumidores. A estratégia de informação aparece quando a marca informa para os fãs da página como a empresa surgiu e as dificuldades encontradas inicialmente. 
Figura 06: Postagem que divulga desenhos dos usuários

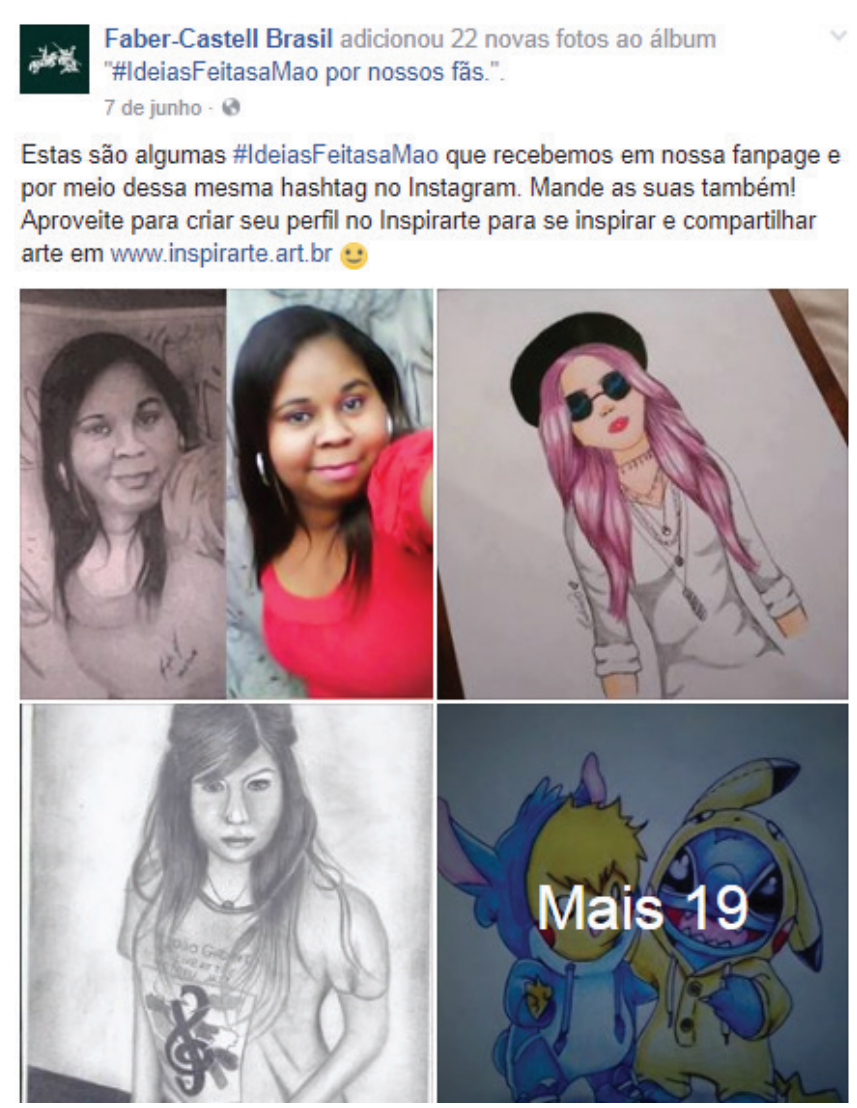

Fonte: Disponível em: <https://www.facebook.com/fabercastellbrasil/?ref=br_rs>. Acesso em: 07 jun. 2017.

A marca publicou 22 fotos e, por meio da legenda, encoraja outros usuários a participarem e a criarem um perfil no site Inspirart. Com 22 desenhos, o post recebeu 5 mil reações, 4,3 mil curtidas, 482 amei, 2 haha, 174 uau, 2 triste, 3 grr e 31 gratidão. A estratégia de comunicação observada foi a de informação, que permite à marca se aproximar do público-alvo, por meio da mostra de trabalhos realizados por outros usuários, além de informar sobre a plataforma de cadastro Inspirarte.

Ensinamentos também são utilizados e este exemplo está bem claro na Figura 06, acima, cujo post "dica" tinha uma legenda simples, curta e divertida em que a marca aposta em breves instruções de desenvolvimento de desenhos, no caso ensinando o desenho de uma vaquinha, para se aproximar do público e conseguir engajamento.

Após as análises, é possível tecer algumas considerações finais sobre o comportamento da empresa na rede social, que apontam que a comunicação que a Faber-Castell Brasil mantém no ambiente online, está de acordo com seu posicionamento, e por meio da estratégia de comunicação de infor- 
mação, a marca consegue aumentar a visibilidade da empresa nessa mídia social e alcançar engajamento com seu público na página.

Quadro 06: Resumo das postagens selecionadas do corpus de 41 postagens

\begin{tabular}{|c|c|c|c|c|c|}
\hline $\begin{array}{c}\text { Data da } \\
\text { Publicação }\end{array}$ & Tipo & Estratégia & Reações & Comentários & $\begin{array}{c}\text { Compartilha- } \\
\text { mentos }\end{array}$ \\
\hline $26 / 07 / 2017$ & Desenhos & Informação & 9.300 & 12.454 & 201 \\
\hline $07 / 06 / 2017$ & Desenhos & Informação & 5.000 & 525 & 301 \\
\hline $12 / 06 / 2017$ & Vídeo & $\begin{array}{c}\text { Informação } \\
\text { e posiciona- } \\
\text { mento }\end{array}$ & 38.000 & 1.059 & 154 \\
\hline $18 / 06 / 2017$ & Desenho & Informação & 38.000 & 1.216 & 2.244 \\
\hline $03 / 06 / 2017$ & Desenho & Informação & 4.8000 & 80 & 123 \\
\hline
\end{tabular}

Fonte: elaboração própria

As postagens analisadas ilustraram convites para interagir, divulgaram desenhos dos usuários, divulgaram a marca, de forma geral, trouxeram dicas aos usuários e, ainda, divulgaram produtos específicos. Percebemos que a estratégia de informação é a que está mais presente nas ações da Faber Castell, na rede social Facebook, e que os desenhos dominam as postagens, possivelmente por remeterem ao uso do principal produto da empresa.

A presença digital é trabalhada no Facebook produzindo conteúdo relevante frequentemente para o público-alvo que se identifica e interage com a marca. $O$ tipo de postagem que mais gerou engajamento foi quando a empresa convidou para interagir, mas espontaneamente e quando solicitado, o público se fez presente.

Neste estudo, constatou-se que a presença digital da empresa é vista como uma organização que se preocupa em manter um relacionamento com os usuários, procurando responder aos comentários em suas publicações, sempre que possível.

\section{CONSIDERAÇÕES FINAIS}

Na presente pesquisa, foi possível contextualizar a ambiência digital e a proporção que ela está e segue conquistando junto às marcas e às pessoas. Revolucionando a maneira de se comunicar, o online é buscado cada vez mais pelas organizações, na tentativa de manter a ligação com os clientes e da própria empresa em se manter atualizada. 
Como objeto deste estudo, a marca Faber-Castell que tem mais de 250 anos, vivencia, desde 2010 no Brasil, a experiência do contexto tecnológico através de uma página no Facebook.

O objetivo do trabalho elaborado foi analisar as estratégias comunicacionais da marca na rede social, para ampliar sua visibilidade nesse ambiente, que por sua maioria foi a estratégia de informação. Essa, segundo Lupetti (2007), tem o propósito de informar o público-alvo sobre os produtos ou serviços oferecidos, essa estratégia se adequa ao tipo de publicação que a marca faz na rede social, onde a maioria de suas postagens divulga produtos. Outra estratégia que aparece é a de posicionamento, que permite à organização criar uma imagem positiva da marca na mente do consumidor.

Após analisar as estratégias de comunicação utilizadas, foi possível constatar como acontece a presença digital da marca, que está direcionando seus esforços cada vez mais em mídias online diversas e pouco em mídias offline. Strutzel (2015) aponta as fases da presença digital em quatro momentos e, através da análise feita, foi possível perceber que a Faber-Castell alcança todos os níveis.

Na primeira etapa, é preciso que a empresa reconheça, exista e adote a cultura do ambiente digital. Destaca-se que a Faber-Castell está presente na rede social há mais de 5 anos. A segunda etapa é a da atração, que diz respeito à frequência, à relevância, ao equilíbrio e à qualidade do conteúdo produzido pela marca. Mesmo sem um padrão definido para postar conteúdo, a marca posta com frequência. A terceira fase é o relacionamento, que é o acompanhamento que a marca faz para saber como o público reage ao seu conteúdo. Já a quarta e última fase é a do engajamento.

Quanto a essa última etapa, foi possível verificar que o tipo de postagem que obteve mais sucesso foram as publicações em que a Faber-Castell convida os usuários a interagirem, por meio de comentários e exibição de trabalhos realizados pelos mesmos. E o posicionamento "sua companhia para toda vida" estava presente de forma implícita, ou seja, a marca não expõe em texto, mas faz referência a ele em todas as publicações, quando dirige sua comunicação ao público adulto, reforçando a mensagem de que a marca não é apenas para crianças em fase escolar.

As publicações são de caráter informal, sem auxílio de legendas rebuscadas e a maioria divulgava os produtos da marca porém sem preço, ressaltando a qualidade e o diferecial de cada um através de textos com tons divertidos e postagens coloridas. Essa estratégia de discurso está baseada 
no público-alvo da marca que são adultos, artistas e buscam conteúdos e dicas relacionados ao mundo da escrita e técnicas de desenho.

Pelo fato de o segmento de mercado da empresa ser voltado para produtos de papelaria, escritório e escrita, a maioria das postagens foi feita por meio da técnica de ilustração, demonstrando, assim, que a marca se preocupa em manter a essência de seus produtos em conexão com sua comunicação, além de incentivar e dar espaço ao público que também exerce de forma profissional ou amadora, o amor pelo desenho.

A empresa, que é mundialmente conhecida, administra sua comunicação de uma maneira integrada e personalizada, de acordo com cada país que atua, através da rede social Facebook, que permite esta ação. Importante frisar que para cada país a produção de conteúdo é diferente, permanecendo as categorias abordadas neste trabalho: foto, vídeo e desenho com divulgação de produtos e dicas de ilustração.

Outos aspectos a respeito da empresa ainda merecem ser estudados, como a atuação da marca em outras plataformas, como Instagram e aplicativos, além da relação existente entre todas as mídias sociais em que atua.

\section{REFERÊNCIAS}

ADOBE. Digital Advertising Report. 20/10/2015. Disponível em: <https://www.slideshare. net/adobe/adobe-digital-indexs-q3-digital-advertising-social-intelligence-report/>. Acesso em: 04 mai. 2017.

ANGELONI, Maria Terezinha. Comunicação nas organizações na era do conhecimento. São Paulo: Atlas, 2010.

BARDIN, Laurence. Análise de conteúdo. Lisboa: Edições 70, 1977.

BARICHELLO, Eugenia Mariano da Rocha. Visibilidade midiática, legitimação e responsabilidade social: dez estudos sobre as práticas de comunicação na Universidade. Eugenia Mariano da Rocha Barichello, (org). - Santa Maria :FACOS/UFSM ; [Brasília] : CNPq, 2004. $366 \mathrm{p}$.

BETHANY; AMANDA. Whoa, wait. Walmart? Blog. Disponível em: <http://whoawaitwalmart.com/> Acesso em: 12 abr. 2017.

CHIZZOTTI, A. Pesquisa qualitativa em Ciências Humanas e Sociais. 3. ed. Petrópolis: Vozes, 2006.

FABER Castell. História da Faber Castell. Disponível em: <http://www.faber-castell.com. br/docs/default.aspx?id=19578\&addminprt=1>. Acesso em: 20 mar. 2017.

FOLHA de São Paulo. Tec. Internet já tem quase 3 bilhões de usuários no mundo, diz ONU. 25/11/2014. Disponível em: <http://www1.folha.uol.com.br/tec/2014/11/1553088-internet-ja-tem-quase-3-bilhoes-de-usuarios-no-mundo-diz-onu.shtml> Acesso em: 12 abr. 2017. 
GABRIEL, Martha. Você, eu e os robôs: pequeno manual do mundo digital. São Paulo: Atlas, 2018.

GFK. Somos a GfK. Disponível em: <http://www.gfk.com/pt-br/>. Acesso em: 27 mar. 2017. IAB Brasil. Investimento em publicidade digital no Brasil. 2018. Disponível em: < https://iabbrasil.com.br/infografico-iab-brasil-pesquisa-digital-adspend-2018-2/> Acesso em: 10 fev. 2019.

KOTLER, Phillip. Princípios de Marketing. Rio de Janeiro: PHB, 1998. Marketing para o Século XXI. São Paulo: Futura, 1999.

KOTLER, Phillip. Administração de Marketing: Análise, planejamento, implementação e controle. $4^{\text {a }}$ ed. São Paulo: Atlas, 1996.

KOTLER, Phillip. Administração de Marketing. São Paulo: Prentice Hall, 2000.

LAMB, Charles W. Jr., et al. Princípios de marketing. São Paulo: Pioneira Thomson Learning, 2004.

LEITE, Fábio Furtado. Presença Digital: uma estratégia de negócios necessária. [S.I.], 2016.

LEITE, Fábio Furtado. Presença Digital: uma estratégia de negócios necessária. Disponível em: <http://www.furtadoleite.com.br/presenca_digital/>. Acesso em: 12 abr. 2017.

LI, Charlene. Liderança Aberta: como as mídias sociais transformam o modo de liderarmos. São Paulo: Évora, 2011.

LUPETTI, Marcélia. Gestão estratégica da comunicação mercadológica. São Paulo: Thompson Learning, 2007.

MICHEL, Maria Helena. Metodologia e pesquisa científica em ciências sociais. 2. ed. São Paulo: Atlas, 2009.

PÉREZ, Rafael Alberto. Pensar la estratégia: outra perspectiva. Buenos Aires: La Crujía, 2012.

PERON, Alan. Marketing Digital. [Infográfico] Facebook Marketing - Dados de 2016 da Maior Rede Social do Mundo. 31/05/2016. Disponível em: <http://www.allanperon.com.br/ facebook-marketing/>. Acesso em: 04 mai. 2017.

PORTER, Michael. Estratégia Competitiva: técnicas para análise de indústrias e da concorrência. 17. ed. Rio de Janeiro: Campus, 2004.

RIES, Al; TROUT Jack. Posicionamento: a batalha por sua mente. São Paulo: Pearson Makron Books, 2002.

SAAD, Beth. Estratégias 2.0 para a mídia digital. São Paulo: Editora Senac. São Paulo, 2003.

SARAIVA, Alessandra. Valor econômico. Mais da metade da população brasileira acessa a internet, aponta IBGE. 06/04/2016. Disponível em: <http://www.valor.com.br/brasil/4513070/mais-da-metade-da-populacao-brasileira-acessa-internet-aponta-ibge>. Acesso em: 22 mar. 2017.

STRUTZEL, Tércio. Presença Digital: estratégias eficazes para posicionar sua marca pesso- 
al ou corporativa na web. Rio de Janeiro: Alta Books, 2015.

STRUTZEL, Tercio. Administradores. Os 4 pilares da presença digital. [S.I.]. 24/09/2013. Disponível em: <http://www.administradores.com.br/artigos/marketing/os-4-pilares-da-presenca-digital/73194/>. Acesso em 12 abr. 2017.

TECNOLOGIA e Ciência. Portal R7. Estudo revela que brasileiro passa mais de nove horas por dia na internet. 22/01/2015. Disponível em: <http://noticias.r7.com/tecnologia-e-ciencia/estudo-revela-que-brasileiro-passa-mais-de-nove-horas-por-dia-na-internet-23012015>. Acesso em: 22 mar. 2017.

THOMPSON, Jhon. A nova Visibilidade. Disponível em: <www.revistas.univerciencia.org/ index.php/MATRIZes/article/dowload/5230/5253>. Acesso em 21 nov. 2016.

TI, Inside Online. Comércio eletrônico no Brasil movimenta $\mathbf{R}$ 18,6 bilhões no primeiro semestre. Disponível em: < http://convergecom.com.br/tiinside/home/internet/19/08/2015/comercio-eletronico-movimenta-r-186-bilhoes-no-brasil-no-primeiro-semestre/>. Acesso em: 15 mai. 2017.

TURCHI, Sandra R. Estratégias de marketing digital e e-commerce. 2. ed. São Paulo: Atlas, 2018.

VALENTE, Jonas. Facebook chega a 127 milhões de usuários no Brasil. 20/07/2018. EBC. Disponível em: http://agenciabrasil.ebc.com.br/economia/noticia/2018-07/facebook-chega-127-milhoes-de-usuarios-no-brasil Acesso em 10 fev. 2019.

WOLCOW, Vitor. Como construir uma presença digital eficiente para o seu negócio. Belo Horizonte, 2015. 


\section{Raíssa Grígolo da Silva}

Graduada em Publicidade e Propaganda pela Universidade Franciscana.

E-mail: raissa_grigolo@hotmail.com

\section{Taís Steffenello Ghisleni}

Orientadora. Publicitária, Doutora em Comunicação (UFSM). Professora do Curso de Publicidade e Propaganda e do Mestrado em Ensino de Humanidade e Linguagens da Universidade Franciscana.

E-mail: taisghisleni@yahoo.com.br 